Cambridge University Press

978-1-108-84265-5 - Byron Among the English Poets

Edited by Clare Bucknell , Matthew Ward

More Information

CHAPTER I 3

\title{
'Lord Byron, poh! the man wot writes the werses?': John Clare, Byron and Class
}

\author{
Simon Kövesi
}

In his social context, 'peasant poet' John Clare was not odd in being a constant reader of the 'aristocrat poet' Lord Byron. Even after the latter's attacks in English Bards and Scotch Reviewers on 'cobbler' poets, along with all 'sons of needless trade' who might rhyme ('weavers', 'taylors', labourers with 'plough' or 'spade'), Byron remained a leading influence on labouring-class poets' work. Introducing his volume of labouring-class poetry of the first thirty years of the nineteenth century, Scott McEathron argues that along with Burns and Bloomfield, Byron loomed large for poor poets, including Clare:

perhaps partly because of his avowed hostility, he served several of these figures as a force to grapple with, to imitate, and sometimes to impersonate. Further, the aggressive self-indulgence of his verse, especially Don Juan but including Childe Harold's Pilgrimage, seems to have suggested a new avenue of artistic empowerment, and his influence is clear (and often announced) in the vein of wit, satire, and iconoclasm. ${ }^{2}$

Duncan Wu, meanwhile, gets fired up by the notion that Byron was taken up as a liberal hero ${ }^{3}$ - making a mistake as he does so, in assuming that myths and fantasies, public relations and public desire for heroes, are any less important than facts. To an extent, fine-grained decades-long reader of Byron though he was, Clare was caught up in that same mythology and idol-worship, as we shall see.

Even with positivistic models explaining why Byron might have been appealing to the poor, some critics still fumble and, I think, reveal their own awkwardness around the social gap between poet and readers. I hope we have now moved beyond the idea that Clare enjoyed 'his poetic function as a rustic and uncultivated Byron'. ${ }^{4}$ The assumptions such notions reveal remain prevalent in readings that suggest Clare responds to Byron (as indeed to all literary culture) from a place of lack - of deficiency, of absence, almost of disability. 'Poor Clare's has been the oft-repeated cry of sympathy since he 
Cambridge University Press

978-1-108-84265-5 - Byron Among the English Poets

Edited by Clare Bucknell , Matthew Ward

More Information

first appeared on the literary scene in 1820 , pitched by his editor as a poet 'perhaps the least favoured by circumstances and the most destitute of friends of any that ever existed'. ${ }^{6}$ Clare's schooling was limited, his travel and his horizons similarly so, and his ordinariness is understood as limiting in its turn both his range and, often, his critical interest. This is a matter of class - how it is understood both in the Romantic period and the critical here and now. Turning to Clare's reading of Byron helps us contextualise this further. Placing the two poets together, I suggest, allows us to see how Clare addresses his own sense of place and mobility with reference to Byron's lordly licence and enigmatic wanderings. Byron's huge cultural significance by the time Clare first encounters his poetry encourages the younger poet to reflect on how he might make his own mark.

In a still-pertinent essay, 'Is the Academy Ready for John Clare?', David Simpson posited that '[p]erhaps ecocriticism will be Clare's passport to wider recognition'. 7 Twenty-two years later Simpson's projection has indeed come to pass, while Byron is arguably still awaiting full recognition for his value in the environmental humanities. Yet laudably green-minded demonstrations of Clare's proto-environmentalism can sometimes be unintentionally ahistorical and accidentally patronising; while in their positive emphasis on locatedness, they root Clare in a post-Wordsworthian particularity of place which is limiting. Broad assumptions regularly surface about the simple story of Clare's contentment at home, and his madness when uprooted - as if he were a delicate plant, the ultimate expression of Romantic organicism. Sometimes it feels as if we have merely reinforced Arthur Symons's notion of 1908 that if Clare 'was torn up by the roots ... the flower of his mind withered' - especially in our hunt for Romantic examples of the psychological impact of environmental harm that prove the 'relevance' of the period to our own. ${ }^{8}$

With this sheer force of placing in mind, when we look at Clare geographically in comparison to the supranational Byron, there are two directions in which critical responses go. We praise Clare for being of the oikos, of a place, of a dwelling, for feeling an environmental responsibility to the 'glocal', in contrast to 'Byron-the-social-critic', exile, man of the world - at the opposite pole of Romanticism to Wordsworth, at any rate - as J. Andrew Hubbell puts it in a convincing survey of this traditional kind of positioning in Romanticism. ${ }^{9}$ Or, we belittle Clare's limited horizons and presume, just like his early patrons, that he was better off in one place because travelling to London or anywhere else 
Cambridge University Press

978-1-108-84265-5 - Byron Among the English Poets

Edited by Clare Bucknell , Matthew Ward

More Information

would have been too much for him, would have wrecked him. Running through these narrative threads is the final proof that rests in his supposed madness and decades-long end in asylums. In almost any comparative direction, then, Clare risks being diminished, cosily put in his place, while a poet like Byron is thought capable of redefining any space as Byronic.

If Clare has largely been overlooked as a serious commentator on Byron in Byron scholarship, in Clare scholarship, by contrast, the nature of his response has received considerable analysis. Much of the focus has been placed upon Clare's remarkable creative rewritings of Don Juan and Childe Harold from I84I, when Clare was resident in his first asylum in Epping Forest - even if most critics call them 'imitations' because the lazy assumption is that Clare believed he was Byron. ${ }^{10}$ His Byronic texts, read thus, tend to become poems of madness, of delusion, rather than of agency or artistic intention. But there are other ways into the relationship. Most notably, Lynne Pearce has used the theoretical mechanism of Bakhtinian dialogism to explore and empower Clare's responses to Byron. ${ }^{\text {II }}$ Philip Martin and Roger Sales have also developed approaches which return agency to Clare's emulations of Byron in innovative ways. ${ }^{\text {I2 }}$ Adam White has steered away from many of Clare's I84I responses to Byron, alert to the multiple moments of Byron's influence across the length of a poetic life, and seeing Clare as following 'the tradition of Romantic Spenserianism after Byron's innovative example'. ${ }^{13}$ It is to the wider reach of Clare's reading of Byron that this chapter also points, though in order to open up new ground in the relation I focus in the main on the prose.

In what was to become a lifelong commitment to the reading, reinterpretation and rewriting of one poet by another, Clare's earliest encounter with Byron had nothing to do with poetry at all. In his autobiographical writings there is an account of Will Farrow, a sociable Helpston wit in whose shop 'young ploughmen and labour[er]s' hung out of an evening. Clare turns to Farrow's sibling Tom:

he has a brother living now who was a sailor 2I years and who kept a Journal of his life which he got me to copy out in part there was nothing particular in it but a mention of Lord Byron who saild in the same ship and was known among the sailors as a Traveller and not as a poet and I myself was ignorant of him alltogether when I copied out his account of him

I cannot ascertain what time it was when he saild with him but doubtless child Harrold had no existance with the world then 
Cambridge University Press

978-1-108-84265-5 - Byron Among the English Poets

Edited by Clare Bucknell , Matthew Ward

More Information

\section{SIMON KÖVESI}

I have since reflected on this interesting circumstance and often tryd to remember it he describd him as a odd young man lame of one foot on which he wore a cloth shoe who was of a resolute temper fond of bathing in the sea and going ashore to see ruins in a rough sea when it required 6 hands to manage the boat such additional trouble teazd the sailors and teazd them so much that his name became a bye word in the ship for unessesary trouble Tom Farrow I believe was then an ableseaman in the Fox Cutter ${ }^{\text {I4 }}$

While there is much about Byron here that rings true - the swimming, the lameness, the explorative curiosity, the adventurous disregard for safety, the indifference to the serving-classes' disapproval - there's a historical mistake. The hired naval cutter Fox was a 70-ton ship, first at sea in 1757 but sunk forty years later at the battle of Santa Cruz off Tenerife, with the loss of seventeen of its men. ${ }^{15}$ Byron initially sailed on the Princess Elizabeth to Lisbon in 1809 , and the packet called Townshend took his party onwards from there: no Fox was involved in his travels. ${ }^{16}$ Perhaps long-serving sailor Farrow was a survivor of Nelson's defeat at Santa Cruz and Clare accidentally conflated his military and civilian sailing adventures? If so, nothing of the seaman's stories is worth Clare recollecting, other than his encounter with Byron. The important point here is that Byron enters Clare's consciousness as an international traveller - an annoyingly curious one at that - fragmented and mythologised by a sailor's poor recollection of his hard-won tales. Byron is characterised as an explorer seeking ruins, a man looking to put himself in new, alien places and courting danger recklessly at every turn, and he is associated with military adventure too, even if unintentionally.

Clare's initial encounters with Byron as a poet came at a formative time. In December I8I9, the month before his first book of poems appeared, Stamford man of letters Octavius Gilchrist was engaged in a correspondence with Clare and lending him books. In Clare's earliest extant letter to Gilchrist, he writes: 'I return Wordsworth ... I Beg the favour "Lord Byron" that Vol which has the smaller poems'. ${ }^{17}$ On I7 December I8I9, Gilchrist replies with characteristic warmth:

... I shall send the 3rd Vol: of Byron, which you requested, and the 4th Vol, which you did not require, because I wish you to read the third Canto of Childe Harold: if my judgement do not deceive me, you will be much pleased with it. I think I went every step of the road which he describes; - as well as to the Chateau of Chillon which forms the subject of the first poem in that volume. Adieu. If you are at Stamford on Sunday, let us see you. ${ }^{\mathrm{I}}$ 
Cambridge University Press

978-1-108-84265-5 - Byron Among the English Poets

Edited by Clare Bucknell , Matthew Ward

More Information

'Lord Byron, poh!': Clare, Byron and Class

Gilchrist was right: Clare was hooked. As he expectantly awaited publication of Gilchrist's essay introducing him to the literary world in the very first issue of the London Magazine, ${ }^{\text {I9 }}$ to be followed a matter of days later by publication of his first book, he wrote again: 'I Return "Byrone" I Vol. \& beg the Favour of the other a little longer wishing to read "Child Harold" a Second Time I am anxious to Enquire-What says the "London Mag"?"20 Crucially, Clare's concern about the most significant public moment yet in his fledgling career comes after he has asked for more Byron. Gilchrist passes Clare the most Wordsworthian part of Byron's poem - and the part widely celebrated for its account of nature. This was formative reading for Clare, just before he became a public literary figure himself as a poet closely aligned with the natural world.

This early desire to read Byron, born of a new literary friendship, never left Clare. Just a few short months later, Gilchrist was in the storm of the Pope-Bowles controversy; he took Clare along for the ride. The history of this small battle in that much broader 'seven years war of words ${ }^{21}$ runs as follows: William Lisle Bowles attacked Gilchrist in a publication of I820, mistakenly taking Gilchrist for the author of a piece in the Quarterly Review which had lambasted him. Bowles identified Gilchrist as 'the same critic who figured, also, in the same Review last month upon certain productions of a "Poet of nature". If so, his praise or blame may be held in equal contempt'. ${ }^{22}$ When Gilchrist published his forty-two-page pamphlet in response to Bowles in December 1820, he included a four-page defence of Clare - the 'Poet of nature' in question - and quoted two of Clare's published sonnets in full: 'To the Winds' and 'Anxiety'. ${ }^{23}$ Bowles had quoted Byron, so Gilchrist - significantly - cited him too, but not at length. A fortnight after Gilchrist's pamphlet appeared, Clare wrote in warlike terms to his editor John Taylor:

Mr O[ctavius] G[ilchrist] has gibbetted me in his answer to Bowles on high ground as a sonneteer I wish he had said less twill raise a nest of wasps \& bring an old house over ones head \& I expect ye will see a blackguard letter in the 'London' or the 'New Monthly' from the Northamptonshire Peasant to L[ord] B[yron] who has doubtlessly mediated a stripe on my shoulders with his cane ere now from O.Gs pamphlet - if he meddles with me any where I'll thrash him with plenty of foul mouthd words depend on' $t^{24}$

There is surprised anxiety here at the public exposure to criticism Gilchrist has risked with excessive praise. But Clare's concern quickly moves to the potential fallout from direct, personal exposure to Byron's censure. Could 
Cambridge University Press

978-1-108-84265-5 - Byron Among the English Poets

Edited by Clare Bucknell , Matthew Ward

More Information

it be that English Bards made any labouring-class poet worry they might receive the same rough treatment that the Bloomfield brothers suffered? Or was the list of poets Byron had condemned a club Clare secretly wanted to join? To his editor, Clare fantasises about doing battle directly with Byron in the press and imagines Byron beating him with 'his cane', suggesting he felt threatened as well as energised by the violence of class: what is proposed here is essentially a servant's corporal punishment from a tyrannical Lord. Yet he maintains with bravado that he is ready with the poor-man's arsenal: bad language. Not having read Byron's private papers, perhaps Clare felt his class and culture gave him access to words more 'foul' than a pampered aristocrat could imagine.

Would Clare have been disappointed that when Byron did reply the following year with his own published pamphlet, he did not mention him at all? Clare - by I82I celebrated widely as the latest great 'peasant poet' of nature - might well have been piqued when he read in the pamphlet that Byron despaired at modern trends which suggested nature gave a poet everything. He might also have felt personally Byron's barb that even a drunk peasant could use his imagination to forge something with more value than much modern poetry:

Nature, exactly, simply, barely Nature, will make no great artist of any kind, and least of all a poet - the most artificial, perhaps, of all artists in his very essence ... It is the fashion of the day to lay great stress upon what they call 'imagination' and 'invention,' the two commonest of qualities: an Irish peasant with a little whiskey in his head will imagine and invent more than would furnish forth a modern poem. ${ }^{25}$

Byron uses a nasty English prejudice in circulation at the time: that the peasantry of Ireland was in the most degraded state imaginable. But the peasant poet at this precise moment was Clare. Being reminded so brutally of his status by a Lord in a public debate on poetry must have stung - but it was something Clare anticipated; even wanted, perhaps?

If there was a personal class edge to Clare's appreciation of Byron, it lifted in the wake of the latter's death. Clare composed an eye-witness account of Byron's funeral cortège as it progressed through London on I2 July I824:

I happend to see it by chance as I was wandering up Oxford Street ... my eye was suddenly arested by straggling gropes of the common people collected together and talking about a funeral ... the grope collected into about a hundred or more when the train of a funeral suddenly appeard on which a young girl that stood beside me gave a deep sigh and utterd poor 
Cambridge University Press

978-1-108-84265-5 - Byron Among the English Poets

Edited by Clare Bucknell , Matthew Ward

More Information

'Lord Byron, poh!': Clare, Byron and Class

Lord Byron there was a mellancholy feeling of vanity - for great names never are at a loss for flattere[r]s that as every flower has its insect - they dance in the sunbeams to share a liliputian portion of its splendour - upon many countenances - I lookd up in the young girls face it was dark and beautiful and I coud almost feel in love with her for the sigh she had utterd for the poet it was worth all the News paper puffs and Magazine Mournings that ever was paraded after the death of a poet since flattery and hypocr[is]y was babtizd in the name of truth and sincerity - the Reverend the Moral and fastidious may say what they please about Lord Byrons fame and damn it as they list ... the common people felt his merits and his power and the common people of a country are the best feelings of a prophecy of futurity - they are below - or rather below the prejudices and flatterys the fancys of likes and dislikes of fashion - they are the feelings of natures sympathies unadulterated with the pretentions of art and pride... they felt by a natural impulse that the mighty was fallen and they mournd in saddend silence ... I believe that his liberal principals in religion and politics did a great deal towards gaining the notice and affections of the lower orders ... it is better to be beloved by the low and humble for undisguised honesty then flattered by the great ${ }^{26}$

The account is centrally about the kind of appreciation the 'lower orders' felt for Byron, their 'sympathies unadulterated with the pretentions of art and pride'. It is an extended performance of quite bitter inverted snobbery: the 'common people' are said to feel more directly and uncomplicatedly the resonance of an historical moment and the loss of a liberating figure than polite society, 'the Reverend the Moral and fastidious' - the society which (ostensibly at least) had pushed Byron into exile. By I824 Clare knew Byron's poetry very well, but there is nothing of that textual life here. The focus instead is Byron's public profile, his incredible fame, his apparent distance from polite society's 'pensiond hypocrisy', 'the prejudices and flatterys the fancys of likes and dislikes of fashion', and the consequent sincere 'affections of the lower orders'. Clare gives us a class-based analysis of Byron's cultural significance, and reads permanence into his future fame through the response of the crowds. It amounts to a diffuse journalistic polemic, using Byron's death to condemn the cowardice, insincerity and cant of the powerful. Byron, it appears, was able to effect powerful socialised structures of feeling; in death, he is a lightning rod conducting mass public feeling, and Clare is at the very tip, reaching out in mourning to a brother bard.

But Byron's power continued to worry Clare. His wariness about a potential attack from Byron fuelled his presentation to another labouring-class poet, a couple of months after the funeral. Taking as his opening 
Cambridge University Press

978-1-108-84265-5 - Byron Among the English Poets

Edited by Clare Bucknell , Matthew Ward

More Information

address a line from an 1820 letter he received from Robert Bloomfield, whose huge popularity seems to have provoked the Byron of English Bards to condemn all labouring-class poets, Clare reaches out to his friend Allan Cunningham, the 'Nithsdale Mason', poet, song collector and fellow traveller on the London Magazine scene. ${ }^{27}$ Bloomfield had died in 1823 and his posthumous Remains were published in I824. Because this letter sees Clare self-consciously forging a network among labouring-class poets, it has rightly taken a central place in the history of a developing sense of British class identity and tradition among poets. ${ }^{28}$

Brother Bard and Fellow Labourer,

I beg your acceptance according to promise of this autograph of our English Theocritus, Bloomfield. He is in my opinion our best Pastoral Poet. ... I never forgave Lord Byron's sneering mention of him in the 'English Bards and Scotch Reviewers'; but, never mind, he has left a genius behind him that will live as late as his lordship's; and, though he was but a 'Cobler,' his poems will meet posterity as green and growing on the bosom of English nature and the muses as those of the Peer. I could hazard a higher opinion for truth, but this is enough. Titles and distinctions of pride have long ago been stript of their dignity by the levellers in genius; at least they have been convinced that the one is not a certain copyright or inheritance of the other. I should suppose, friend Allan, that 'The Ettrick Shepherd,' 'The Nithsdale Mason,' and 'The Northamptonshire Peasant,' are looked upon as intruders and stray cattle in the fields of the Muses (forgive the classification), and I have no doubt but our reception in that Pinfold of his lordship's 'English bards' would have been as far short of a compliment as Bloomfield's. ... as we never went to Oxford or Cambridge, we have no Latin and Greek to boast of, and no bad translations to hazard (whatever our poems may be), and that's one comfort on our side. ${ }^{29}$

In class terms, this is possibly the most chippy letter Clare ever wrote. In order to strengthen a bridge of comradeship with an existing acquaintance, he uses Bloomfield as mutualising social glue and Byron as a counterpoint: the external, higher threat whose presence forces these poets to bond. Here, Byron is clearly not a brother in arms but an enemy poet. Yet, when read in the light of the funeral account, composed just two months before, this letter suddenly risks being an exaggerated pose. Clare is writing to another labouring-class poet and wants to impress upon him the quality of his taste, his range of reading, depth of cultural knowledge, and determination to be independently oppositional to the most powerful public figure of the literary world - even after his death. Bloomfield, Cunningham, Hogg and Clare himself are interlopers, trespassing, bovine 'stray cattle' who won't be herded by the 
Cambridge University Press

978-1-108-84265-5 - Byron Among the English Poets

Edited by Clare Bucknell , Matthew Ward

More Information

'Lord Byron, poh!': Clare, Byron and Class

husbandry of the polite society of letters, or delimited by its territories. But even as he dismisses this policed literary terrain, Clare clearly wants to be there, chewing the cud on Parnassus. In Byronic fashion, he enjoys the fight, revels in the status of 'intruder', and is driven by a degree of rebellion.

My question is an antithetical one: are Clare's comments sincere? How can Clare regard Byron as a liberating hero for the masses one moment and a tyrant maintaining socio-literary decorum the next, and be equally sincere in both designs? Or is that paradoxical doubling Clare's perfect reading of real opposing facets of Byron? A further complication stems from the letter's provenance. The explanation for the orthodox spelling and pristine punctuation of the quotation above is that we have only Clare's first biographer's transcription, rather than anything in Clare's own hand. Frederick Martin's 1865 life is a heady admixture of fact and fantasy, pioneering though it certainly was. ${ }^{30}$ While it is unlikely that Martin forged the letter, the text must at least have a question mark hanging over it, particularly because it is quite unlike anything else Clare wrote about the poetic and educational landscape. Then again, the rage that bubbles just under the surface is of a piece with his more violent anticipation of a head-to-head conflict with Byron in I820. It was by no means his only political tune, but when provoked by threat, by scenes of extreme poverty, inequality and the political neglect of the poor - or when it was tactically efficacious, as here - Clare could be as angry about class as anyone, and his response to Byron is bound up with it.

By way of closing, we turn to Clare's Byronic writings of I84I. Clare was by this time resident in an asylum at High Beach, Epping Forest, in Essex. The editor Cyrus Redding met him there in the spring of I84I and wrote an essay about his visit, in which he notes that Clare

spoke of his loneliness away from his wife, expressing a great desire to go home, and to have the society of women. He said his solace was his pipe - he had no other: he wanted books. On being asked what books, he said BYRON ... ${ }^{3 \mathrm{I}}$

Redding does not conjecture as to why Byron, and why only Byron. By this time, Clare had been reading Byron for more than twenty years, but there is a new urgency here in his desire for even more, which is doubtless a product of his institutionalised situation. Clare gave Redding a number of new poems to be published in his English Journal, but his Byronic poems he did not offer or mention at all. His Byron rewritings remained hidden 
Cambridge University Press

978-1-108-84265-5 - Byron Among the English Poets

Edited by Clare Bucknell , Matthew Ward

More Information

and entirely private. But Clare meticulously noted the receipt of Redding's gifts of many Byron volumes:

Recieved from C. Redding while in Prison on Leopards Hill Eleven books on loan \& two Given \& the rest returnable - viz - Child Harold - Reddings Poems - \& following lent viz Don Juan I Vol 5 cantos - 2nd Part Cants 6.7.8 Part 3rd Cants 9.IO.II - Part 4th I2.13.14 - Part 5th Cants I5,16. ${ }^{32}$

Clare was always excited by books - and it seems never more so than when in receipt of more Byron. Taking direct inspiration, in the very same notebook he wrote and rewrote two poems concurrently, interspersed with poetic Biblical paraphrases: his own 'Don Juan A Poem' and 'Child Harold'. To say that the texts are interwoven is an understatement: on the first page of one small notebook the first stanza of his 'Don Juan' appears, followed by the opening stanza of his 'Child Harold', followed by a ballad, while a Biblical paraphrase is written vertically opposite on the inside front cover. ${ }^{33}$ Editors have struggled to rationalise secure orders for these formally and thematically separate poems, along with the various paratexts in the manuscript books. ${ }^{34}$ Indirectly, the Byronic poems each constitute learned commentaries upon Byron's originals; or rather, they amount to concentrated, acidic distillations of particular facets of them. Clare owned one of the many piratical 'continuations' of Don Juan, an anonymous I825 publication by the London-based American poet Isaac Clason. Uninspiring and moralising though it is, this book might have planted the seed for Clare's own reworkings. ${ }^{35}$

Where Clare's 'Child Harold' is plaintive, sincere, nostalgic, weatherbeaten and full of Clarean (and Byronic) recourse to the natural world, his 'Don Juan' is caustic, contemporary and cantankerous. It rails against the state of society, the condition of poetry and the depravities and indiscretions of woman. It is misogynistic towards specific 'wives' and towards the young Queen Victoria - who had succeeded to the throne in June I837, just a couple of weeks before Clare first entered the asylum. His poem repeatedly implies that Victoria was cuckolding Prince Albert and having an affair with her prime minister Lord Melbourne - who himself had been cuckolded by none other than Byron decades before. Though his poems do not share the tonal variance and plurality offered by Byron's poems, Clare knew his Byron, poet and lore. Following Byron's innovative model in Don Juan of self-awareness and self-reflexivity, Clare's 'Don Juan' directs itself at its own making and at the sufferance and moral complicity of the reader. As many critics have attested, it is a highly sophisticated allusive response. What is not so apparent, however, is the class differential that we have seen 
Cambridge University Press

978-1-108-84265-5 - Byron Among the English Poets

Edited by Clare Bucknell , Matthew Ward

More Information

'Lord Byron, poh!': Clare, Byron and Class

bothering Clare so much in the past. I would argue, though, that it was precisely the fact of Byron's elevated social position and what it offered the asylum-bound, deracinated Clare that drew him to his predecessor again, and in such fervid fashion: Byron offered him confidence, the ability to write himself up to a platform from which he could talk about anyone, of any status, in any manner he pleased. The gulf in class between the two was doubtless an important component of Clare's attraction. Byron, at this point, represented poetic licence.

I want to close with a moment which reveals just how complex Clare's ventriloquism of Byron could be. Byron's birthday was 22nd January; Clare's I3th July. In Tim Chilcott's edition, these ottava rima stanzas appear about two-thirds of the way through 'Don Juan':

Now this day is the eleventh of July

$\&$ being sunday I will seek no flaw

In man or woman - but prepare to die

In two days more I may that ticket draw

\& so may thousands more as well as I

To day is here - the next who ever saw

$\&$ In a madhouse I can find no mirth pay

- Next tuesday used to be Lord Byron’s birthday

Lord Byron poh - the man wot rites the werses

$\&$ is just what he is $\&$ nothing more

Who with his pen lies like the mist disperses

$\&$ makes all nothing as it was before

(11. 223-34)

There is much that could be said here - of the way Clare conflates his biography with Byron's; of the way he talks of mortality with exactly the same attitude and voice as the narrator of Byron's Don Juan - relaxed, sweeping, self-referential, intimate; of the final couplet's Hudibrastic, polysyllabic, clunky rhyme. At the start of the second stanza, the magic incantation 'Lord Byron' is repeated, but its bubble is popped immediately with the plosive 'poh' - a sound of the mouth, not a word of the page. And then Clare has a quick costume change to adopt a mock-cockney accent an exclamation with its 'w's and 'r's muddled up - and suddenly we hear an affected working-class Londoner. A street-trader dismisses a Lord with a 'poh'. But it is in the second, third and fourth lines that Clare doubles and trebles his meanings, in a way only a master of the form could. By July I84I Byron was indeed 'nothing more' - he was only 'just what he is' text, poetry. But in that poetry he both 'lies' and 'disperses' falsehoods. 
Cambridge University Press

978-1-108-84265-5 - Byron Among the English Poets

Edited by Clare Bucknell , Matthew Ward

More Information

Clare wants to have Byron both ways: as the great fabricator and the great truth-teller. And in the final line quoted above, we have the possibility that Byron transformed everything - Clare included - along with the opposing implication that he effected nothing much at all: that 'all' remains 'nothing as it was before' he published a word. All remains as nothing? Or all is changed, by Byron, from nothing to something? It is surely central to the unsettling impact of Don Juan that even while we grasp for the transforming power of poetry, we are left with the disturbing possibility that the whole adventure has meant nothing much at all.

\section{Notes}

I. George Gordon, Lord Byron, English Bards and Scotch Reviewers. A Satire, 11. 791, 775, 795-96, 776, in $C P W$, vol. I, pp. 253-54.

2. Scott McEathron, ed., Nineteenth-Century English Labouring-Class Poets, I800-I900, 3 vols., gen. ed. John Goodridge (Pickering \& Chatto, 2006), Volume I: $1800-1830$, p. xix.

3. In 30 Great Myths About the Romantics (Wiley Blackwell, 2015), Duncan Wu challenges four myths about Byron: that he 'had an affair with his sister'; that he 'was a great lover of women'; that he 'was a champion of democracy'; and that he 'was a "noble warrior"' (pp. 132-64). Wu might be right that none of these is true. But there is no doubt that the latter three of these myths were significant to Clare, and play a real role in his Byronic rewritings of I84I.

4. M. Byron Raizis, 'Childe Harold's Offspring, English and American', Byron Journal, 27 (1999), 26-37 (p. 27).

5. The phrase appears as many as eleven times in Mark Storey's Clare: The Critical Heritage (Routledge \& Kegan Paul, 1973), in extracts from I820 to I947: see pp. 6I, 72, 83, 9I, 138, 249 (twice), 25I, 256, 268, 270, 28I, 288, 290 and 399.

6. John Taylor, introduction to John Clare, Poems Descriptive of Rural Life and Scenery (Taylor and Hessey, I820), p. vii.

7. David Simpson, 'Is the Academy Ready for John Clare?', John Clare Society Journal, i8 (1999), 70-78 (p. 72).

8. Introduction to Poems by John Clare, ed. Arthur Symons (Henry Frowde, 1908), quoted in $\mathrm{CH}$, pp. 30I-08 (303). I explore the environmentalist phenomenon in the first chapter of John Clare: Nature, Criticism and History (Palgrave Macmillan, 20I7).

9. J. Andrew Hubbell, Byron's Nature: A Romantic Vision of Cultural Ecology (Palgrave Macmillan, 2018), p. 23. For a somewhat ironised study of Byron and Wordsworth as the oppositional 'twin towers' of Romanticism, see Jerome McGann, 'Is Romanticism Finished?', in The Cambridge History of Romantic Literature, ed. James Chandler (Cambridge University Press, 2009), pp. 648-64. 
Cambridge University Press

978-1-108-84265-5 - Byron Among the English Poets

Edited by Clare Bucknell , Matthew Ward

More Information

'Lord Byron, poh!': Clare, Byron and Class

Io. See for example: Edward Strickland, 'Boxer Byron: A Clare Obsession', Byron Journal, I7 (1989), 57-76; Anne Barton, 'John Clare Reads Lord Byron', Romanticism, 2 (1996), I27-48; Simon Kövesi, 'Masculinity, Misogyny and the Marketplace: Clare's “Don Juan A Poem”', in John Clare: New Approaches, eds. John Goodridge and Simon Kövesi (John Clare Society, 200I), pp. I87-202; Jason Goldsmith, 'The Promiscuity of Print: John Clare's "Don Juan" and the Culture of Romantic Celebrity', SEL, I500-1900, 46 (2006), 803-32; Zachary Suetta, 'Blurred Boundaries: Anger, Identity and Satire in John Clare's Don Juan', John Clare Society Journal, 39 (2020), 83-98.

II. See Lynne Pearce, 'John Clare’s "Child Harold”: A Polyphonic Reading', Criticism, 3I (199I), I39-57; Pearce, 'John Clare's "Child Harold”: The Road Not Taken', in Feminist Criticism: Theory and Practice, ed. Susan Sellers (Harvester Wheatsheaf, I99I), pp. I43-56.

I2. Philip Martin, 'Authorial Identity and the Critical Act: John Clare and Lord Byron', in Questioning Romanticism, ed. John Beer (Johns Hopkins University Press, 1995), pp. 7I-9I; Roger Sales, John Clare: A Literary Life (Palgrave, 2002), especially pp. I44-58.

I3. Adam White, John Clare's Romanticism (Palgrave Macmillan, 20I7), p. Ioo.

I4. John Clare By Himself, eds. Eric Robinson and David Powell (Carcanet, I996; repr. Routledge, 2002), p. 65.

I5. As reported by its commander, one Horatio Nelson, who lost his arm in this famous defeat. See European Magazine and London Review, XXXII (I797), 42I-23.

I6. Fiona MacCarthy, Byron: Life and Legend (John Murray, 2002), pp. 91, 97.

17. The Letters of John Clare, ed. Mark Storey (Clarendon Press, I985), p. 23.

I8. Gilchrist to Clare, I7 December I8I9, British Library, Egerton MSS 2245, I7r.

19. Octavius Gilchrist, 'Some Account of John Clare, an Agricultural Labourer and Poet', London Magazine, I (January I820), quoted in CH, pp. 35-42 (40).

20. Letters of John Clare, ed. Storey, p. 24.

2I. See James Chandler, 'The Pope Controversy: Romantic Poetics and the English Canon', Critical Inquiry, Io (March I984), 48I-509 (p. 482).

22. William Lisle Bowles, 'A Reply to an "Unsentimental Sort of Critic," the Reviewer of "Spence's Anecdotes", QR, XXIV (October I820), p. II.

23. Gilchrist, A Letter to the Rev. William Lisle Bowles, in Answer to a Pamphlet Recently Published foc. (Baldwin, Cradock, and Joy \&c., I820), pp. II-I4. The sonnets appear in Clare's Poems Descriptive, pp. 198 and 205.

24. Letters of John Clare, ed. Storey, p. I23.

25. Byron, Letter to *********, on the Rev W. L. Bowles' Strictures on the Life and Writings of Pope (John Murray, I82I), pp. 2, 36.

26. John Clare By Himself, eds. Robinson and Powell, pp. 156-58.

27. For the Bloomfield-Clare letter, see Storey, ed., Letters of John Clare, p. 302, n. 2.

28. See, e.g., John Goodridge, 'Sociable or Solitary? John Clare, Robert Bloomfield, Community and Isolation', in Class and the Canon: Constructing Labouring-Class Poetry and Poetics, I780-I90o, eds. Kirstie Blair and Mina Gorji (Palgrave Macmillan, 2013), pp. 55-76. 
Cambridge University Press

978-1-108-84265-5 - Byron Among the English Poets

Edited by Clare Bucknell , Matthew Ward

More Information

29. Clare to Allan Cunningham, 9 September 1824, in Letters of John Clare, ed. Storey, pp. 302-03.

30. See Frederick Martin, The Life of John Clare (Macmillan and Co., I865), pp. I88-89.

31. Cyrus Redding, 'Clare, the Poet', English Journal, I. 20 (I5 May I84I), 305-09 (p. 305) and I. 22 (29 May I84I), 340-43.

32. Northampton Central Library, John Clare MS 8, p. 60.

33. Ibid., p. I (and opposite p. I on the inside front cover).

34. The best analysis of these manuscripts and the texts therein is offered by Tim Chilcott in the introduction to his edition John Clare: The Living Year I84I (Trent Editions, 1999), pp. vii-xvii. Further references are to this edition and given in the text.

35. Anon., Continuation of Don Juan. Cantos XVII and XVIII (Whittaker, Munday and Slatter, I825). Item 139 in [David Powell], Catalogue of the John Clare Collection in the Northampton Public Library (County Borough of Northampton Public Libraries, Museums and Art Gallery Committee, 1964). 